Available online http://iurnalmahasiswa.uma.ac.id/index.php/iiperta

Diterima: Juli 2020; Disetujui: Agustus 2020; Dipublish: September 2020

\title{
Stimulasi Pertumbuhan dan Perkembangan Planlet Anggrek (Dendrobium Sp) pada Tahap Aklimatisasi dengan Pemberian Vitamin B1 dan Atonik
}

\section{Stimulation of Growth and Development of Planlet Orchid (Dendrobium Sp) in The Acclimatization Stage by suplementing of Vitamin B1 and Atonik}

\begin{abstract}
Riski Abdul Latif, syahbudin Hasibuan dan Siti Mardiana*
Program Studi Agroteknologi, Fakultas Pertanian, Universitas Medan Area, Indonesia

Abstrak

Dendrobium sp adalah jenis anggrek yang saat ini sangat populer diperjual belikan karena memiliki keistimewaan berbagai jenis bunganya tetapi laju pertumbuhannya lambat. Vitamin B1 (Thiamin) adalah salah satu hara mikro yang mampu mempercepat pembelahan sel-sel baru dalam jaringan sehingga dapat mempercepat pertumbuhan organ vegetative tanaman. Tujuan dari penelitian ini adalah Stimulasi Pertumbuhan dan Perkembangan Planlet Anggrek (Dendrobium sp) Pada Tahap Aklimatisasi dengan Pemberian Vitamin B1 dan Atonik. Penelitian ini dilakukan secara eksperimental dengan menggunakan desain Rancangan Acak Lengkap (RAL) dengan 2 faktor, yaitu konsentrasi Vitamin B1 (Thiamin) yang terdiri dari 4 tarap perlakuan dan Atonik yang terdiri dari 4 perlakuan. Vitamin B1 yaitu(0 ml/l, 1,5 ml/l, $3 \mathrm{ml} / \mathrm{l}, 4,5 \mathrm{ml} / \mathrm{l})$ dan Atonik (0 ml/l, $1 \mathrm{ml} / \mathrm{l}, 2 \mathrm{ml} / \mathrm{l}, 3 \mathrm{ml} / \mathrm{l})$ dan masing- masing perlakuan diulang sebanyak 2 kali sehingga dapat 128 tanaman setiap perlakuan terdiri dari 4 tanaman dengan 4 tanaman sampel. Berdasarkan hasil penelitian pada anggrek Dendrobium sp. Dapat diperoleh kesimpulan 1) Pemberian Vitamin B1 berpengaruh nyata terhadap pertumbuhan tinggi tanaman Anggrek (Dendrobium sp). 2) Pemberian Atonik berpengaruh nyata terhadap pertumbuhan jumlah daun, panjang akar dan jumlah akar tanaman Anggrek (Dendrobium sp). 3) Pemberian Vitamin B1 dan Atonik nyata secara bersamaan dapat mempercepat mengatasi tinggi tanamn, jumlah daun dan Pertunasan akar tanaman Anggrek (Dendrobium sp).

Kata Kunci: anggrek (dendrobium sp), vitamin B1, atonic
\end{abstract}

\section{Abstract}

Dendrobium sp is a type of orchid that is currently very popularly traded because it has a variety of flower types, but the growth rate is slow. Vitamin B1 (Thiamin) is a micro nutrient that is able to accelerate the division of new cells in the tissue so that it can accelerate the growth of plant vegetative organs. Atonic is a chemical that can stimulate the biochemical and physiological processes of plants, so that atonics is a growth regulator. The purpose of this study is the Stimulation of Growth and Development of Planlet Orchid (Dendrobium sp) in the Acclimatization Stage by Provision of Vitamin B1 and Atonik. This research was conducted experimentally using a completely randomized design (CRD) with 2 factors, namely the concentration of Vitamin B1 (Thiamin) consisting of 4 treatment groups and Atonic consisting of 4 treatments. Vitamin $B 1(0 \mathrm{ml} / l, 1.5 \mathrm{ml} / \mathrm{l}, 3 \mathrm{ml} / \mathrm{l}, 4.5 \mathrm{ml} / \mathrm{l})$ and Atonik $(0 \mathrm{ml} / \mathrm{l}, 1 \mathrm{ml} / \mathrm{l}, 2 \mathrm{ml} / \mathrm{l}, 3 \mathrm{ml}$ /l) and each treatment was repeated 2 times so that 128 plants could each treatment consisting of 4 plants with 4 sample plants. Based on the results of research on Dendrobium sp. Can be concluded 1) Provision of Vitamin B1 significantly affect the growth of orchid plant height (Dendrobium sp). 2) The giving of Atonik significantly influences the growth of the number of leaves, root length and number of roots of orchid plants (Dendrobium sp). 3) Provision of Vitamin B1 and Atonik simultaneously can accelerate to overcome plant height, number of leaves and the budding of orchid plant roots (Dendrobium sp).

Keywords: Dendrobium Sp, Vitamin B1, Atonic

How to Cite: Riski, A.L. Syahbudin, H. \& Siti, M. (2020), Stimulasi Pertumbuhan dan Perkembangan Planlet Anggrek (Dendrobium Sp) pada Tahap Aklimatisasi dengan Pemberian Vitamin B1 dan Atonik. Jurnal Ilmiah Pertanian (JIPERTA), 2 (2): 127-134.

*E-mail: Riski.al@gmail.com ISSN 2550-1305 (Online)

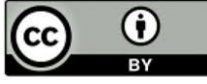

This work is licensed under a Creative Commons Attribution 4.0 


\section{PENDAHULUAN}

Dendrobium merupakan salah satu anggrek yang berpotensi untuk terus dikembangkan karena memiliki beragam jenis bentuk, warna dan ukurannya. Selain itu anggrek dendrobium juga dapat dijadikan sebagai bunga potong maupun sebagai bunga pot. Produksi anggrek potong tahun 2007 menduduki urutan ke 5 setelah gladiol yaitu sebanyak 9.484.393 (Direktorat Jenderal Hortikultura 2003-2007).

Menurut Widiastoety dkk. (2010) anggrek merupakan tanaman hias yang memiliki pasar konsumen relatif stabil tidak tergantung musim. Walaupun banyak genus anggrek yang ada, konsumen lebih cenderung memilih anggrek dari genus Phalaenopsis, Cattleya, Dendrobium, Oncidium, dan Vanda dibandingkan genus Luisia, Eria, dan Cryptostylis karena perawatannya relatif mudah, lebih mudah dibungakan, dan memliki lebih banyak variasi bunga. Dendrobium adalah salah satu anggrek yang memiliki banyak peminat karena relatif mudah beradaptasi di dataran rendah, tidak terlalu memerlukan perawatan khusus, mudah berbunga, memiliki banyak variasi bunga, dan beberapa jenis hibrida yang bunganya tetap harum.

Aklimatisasi adalah masa adaptasi tanaman hasil pembiakan pada kultur jaringan (in-vitro) yang semula kondisinya terkendali kemudian berubah pada kondisi lapangan yang kondisinya tidak terkendali lagi, disamping itu tanaman juga harus mengubah pola hidupnya dari tanaman heterotrop ke tanaman autotrop. Aklimatisasi merupakan tahapan yang sanggat penting untuk dilalui dalam proses perbanyakan in vitro. Adanya perbedaan yang sangat tajam terutama kelembaban dan intensitas cahaya lingkungan di dalam botol dan di luar botol menyebabkan proses aklimatisasi ini merupakan tahapan yang kritis (Riyadi, 2002).

Tahapan aklimatisasi merupakan faktor pembatas dalam mendapatkan bibit anggrek untuk tahap berikutnya hingga siap ditanam pot individu (untuk tanaman berbunga). Hal ini biasanya terjadi karena bibit anggrek yang dihasilkan secara invitro umumnya peka terhadap kondisi lingkungan seperti cahaya, kelembaban, maupun serangan pathogen. Meskipun tahapan pemindahan plantlet cukup sulit, namun secara umum berbagai faktor dari dalam maupun faktor dari luar plantlet memengaruhi pertumbuhan dan perkembangan plantlet di lingkungan ex vitro, diantaranya faktor dari luar plantlet yaitu pemberian zat pengatur tumbuh (ZPT) (Yusnita, 2004).

\section{METODE PENELITIAN}

Bahan yang digunakan dalam penelitian ini adalah terdiri dari Planlet Anggrek Dendrobium sp dari planlet, Vitamin B1, Atonik dan media cocopeat. Alat yang digunakan adalah pisau, pinset, suprayer, alat ukur (rulle, Jangka sorong, thermometer dan hygrometer), jarum suntik dan tray. Metode yang digunakan adalah metode esperimental dengan melakukan pengamatan langsung di rumah kasa laboratorium dengan menggunakan Rancangan Acak Lengkap (RAL) Faktorial yang terdiri dari 2 taraf perlakuan.

1. Faktor 1 Pemberian Vitamin B1:

A0 = Tanpa Perlakuan (Control)

A1 = Vitamin B1 Sebagai Katalisator (1,5 ml/l) 
A2 = Vitamin B1 Sebagai Katalisator $(3 \mathrm{ml} / \mathrm{l})$

A3 = Vitamin B1 Sebagai Katalisator (4,5 ml $/ \mathrm{l})$

2. Faktor 2 Pemberian Atonik

B0 = Tanpa Perlakuan (Control)

B1 = Zat Pengatur Tumbuh Sintesis Atonik $(1 \mathrm{ml} / \mathrm{l})$

B2 = Zat Pengatur Tumbuh Sintesis Atonik $(2 \mathrm{ml} / \mathrm{l})$

B3 = Zat Pengatur Tumbuh Sintesis Atonik (3 ml/l)

\section{HASIL DAN PEMBAHASAN}

\section{Persentase Hidup}

Hasil penelitian menunjukkan persentase (\%) hidup anggrek yang hidup dan mati pada umur 2 MST sampai 6 MST dapat dilihat pada tabel di bawah ini.

Tabel 1. Rataan Persentase Hidup Anggrek Dendrobium sp pada umur 2 MST sampai 6 MST

\begin{tabular}{cccc}
\multirow{2}{*}{ Perlakuan } & \multicolumn{2}{c}{ Tumbuh Planlet } & \multirow{2}{*}{ Persentasi Hidup } \\
\cline { 2 - 3 } & Hidup & Mati & $100 \%$ \\
A0B0 & 8 & 0 & $100 \%$ \\
A0B1 & 8 & 0 & $100 \%$ \\
A0B2 & 8 & 0 & $100 \%$ \\
A0B3 & 8 & 0 & $100 \%$ \\
A1B0 & 8 & 0 & $100 \%$ \\
A1B1 & 8 & 0 & $100 \%$ \\
A1B2 & 8 & 0 & $100 \%$ \\
A1B3 & 8 & 0 & $100 \%$ \\
A2B0 & 8 & 0 & $100 \%$ \\
A2B1 & 8 & 0 & $100 \%$ \\
A2B2 & 8 & 0 & $100 \%$ \\
A2B3 & 8 & 0 & $100 \%$ \\
A3B0 & 8 & 0 & $100 \%$ \\
A3B1 & 8 & 0 & $100 \%$ \\
A3B2 & 8 & 0 & $100 \%$ \\
A3B3 & 8 & 0 & \\
\hline
\end{tabular}

Hasil penelitian menunjukkan bahwa persentase hidup anggrek dengan pemberian vitamin B1 dan atonik yaitu $100 \%$ hidup. Tingginya persentase hidup anggerk tersebut tidak terlepas dari faktor internal dan eksternal. Faktor eksternal seperti suhu, cahaya, kelembapan, $\mathrm{pH}$, nutrisi, dan media anggrek sesuai dengan syarat tumbuhnya. Pemberin Vitamin B1 dan atonik pada media aklimatisasi menunjukkan pengaruh yang nyata dalam merespon pertumbuhan vegetatif anggrek sewaktu aklimatisasi.

Menurut Hartati (2010) pemberian atonik pada anggrek mampu meningkatkan pertumbuhan vegetatif pada saat aklimatisasi. Selanjutnya menurut Limarni (2008) mengemukakan pemberian vitamin B1 mampu mempengaruhi pertumbuhan anggrek pada saat aklimatisasi. Berdasarkan hasil pengamatan pada 2 MST tanaman anggrek tersebut mengalami layu saja dan tidak menunjukkan kematian. 
Menurut Limarni et al. (2008) tanaman hasil kutur in vitro memiliki stomata yang lebih terbuka dan respon stomata yang lebih lambat terhadap kehilangan air serta lapisan lilin kutikula yang kurang berkembang. Lapisan kutikula yang tipis mengakibatkan tanaman akan kehilangan air dalam jumlah cukup besar melalui evaporasi kutikula pada saat tanaman dipindahkan pada kondisi in vivo. Stomata tidak berfungsi dengan sempurna sehingga menyebabkan terjadinya cekaman air.

Menurut Zulkarnain (2009) dalam Andalasari (2014) bahwa defisit air dapat mempengaruhi laju fotosintesis, pada keadaan laju transpirasi yang tinggi, daun akan mengalami layu sementara dan stomata menutup. Dalam keadaan tersebut penyerapan CO2 ke dalam daun akan menurun dan laju fotosintesis menurun. Keadaan seperti ini yang sering menyebabkan tanaman dalam proses aklimatisasi memiliki keberhasilan yang rendah dan persentase hidup yang rendah.

\section{Tinggi Tanaman Anggrek}

Hasil analisis data pada pengamatan tinggi tanaman anggrek pada umur 6 MST (minggu setelah tanam) menunjukkan pengaruh yang nyata pada tinggi tanaman saat aklimatisasi.

Tabel 2. Rangkuman Analisis Sidik Ragam Rataan Tinggi Tanaman Akibat Pemberian Vitamin B1 dan Atonik $(\mathrm{cm})$

\begin{tabular}{lccccccc}
\hline \multirow{2}{*}{ SK } & \multicolumn{3}{c}{ F. Hitung } & \multicolumn{3}{c}{ F. Tabel } \\
\cline { 2 - 8 } & $2 \mathrm{mst}$ & $3 \mathrm{mst}$ & $4 \mathrm{mst}$ & $5 \mathrm{mst}$ & $6 \mathrm{mst}$ & $\mathrm{F}_{0,05}$ & $\mathrm{~F}_{0,01}$ \\
\hline A & $1,06 \mathrm{tn}$ & $1,47 \mathrm{tn}$ & $0,40 \mathrm{tn}$ & $0,97 \mathrm{tn}$ & $4,06 *$ & 3,29 & 5,42 \\
B & $0,92 \mathrm{tn}$ & $0,94 \mathrm{tn}$ & $1,95 \mathrm{tn}$ & $1,18 \mathrm{tn}$ & $0,46 \mathrm{tn}$ & 3,29 & 5,42 \\
AXB & $1,18 \mathrm{tn}$ & $0,51 \mathrm{tn}$ & $2,55 \mathrm{tn}$ & $0,75 \mathrm{tn}$ & $2,07 \mathrm{tn}$ & 2,59 & 3,89 \\
\hline KK & $9,74 \%$ & $2,64 \%$ & $14,26 \%$ & $4,96 \%$ & $12,36 \%$ & & \\
\hline
\end{tabular}

Keterangan: Angka yang diikuti oleh huruf yang sama pada kolom yang sama berbeda nyata pada taraf ? $=0.05$ (huruf kecil) berdasarkan uji jarak Duncan

Berdasarkan tabel 2 MST, perlakuan A merupakan perlakuan terbaik yang berpengaruh terhadap pertumbuhan anggrek dendrobium sp khususnya tinggi tanaman sewaktu aklimatisasi pada umur 6 MST. Pemberian A1 dan A2 merupakan perlakuan terbaik dalam merangsang tinggi tanaman anggrek pada umur 6 MST dengan rata-rata yaitu 13,80 cm dan 13,76 cm. Hal tersebut diduga pemberian Vitamin B1 merupakan perlakuan terbaik yang memengaruhi tinggi tanaman anggrek sewaktu aklimatisasi. Hasil penelitian Limarni (2008) pemberian Vitamin B1 3 ml/l merupakan media terbaik yang memengaruhi pertumbuhan anggrek bulan pada saat aklimatisasi. Hal senada diutarakan Yustitia (2017) pemberian Vitamin B1 $3 \mathrm{ml} / \mathrm{l}$ merupakan perlakuan terbaik yang digunakan untuk proses aklimatisasi anggrek bulan. Penambahan vitamin B1 ini diperlukan sebagai katalisator sekaligus berfungsi sebagai co-enzim (Munir, 2016). Thiamin (vitamin B1) pada tanaman anggrek dapat meningkatkan aktivitas hormon yang terdapat dalam jaringan tanaman sehingga dapat mempercepat pembelahan sel-sel yang baru. 


\section{Diameter Batang (cm)}

Hasil analisis data pada pengamatan jumlah tanaman anggrek pada umur 6 MST menunjukan pengaruh yang tidak nyata pada diameter batang saat aklimatisasi.

Tabel 3. Rangkuman Analisis Sidik Ragam Diameter Batang Anggrek Akibat Pemberian Vitamin B1 dan Atonik (cm)

\begin{tabular}{lccc}
\hline \multirow{2}{*}{ SK } & F. Hitung & \multicolumn{2}{c}{ F. Tabel } \\
\cline { 2 - 4 } & $6 \mathrm{mst}$ & F0,05 & F0,01 \\
\hline A & 3,09 tn & 3,29 & 5,42 \\
B & 0,79 tn & 3,29 & 5,42 \\
AXB & $0,98 \mathrm{tn}$ & 2,59 & 3,89 \\
\hline KK & $30,11 \%$ & & \\
\hline
\end{tabular}

Keterangan: Angka yang diikuti oleh huruf yang sama pada kolom yang sama berbeda nyata pada taraf ? $=0.05$ (huruf kecil) berdasarkan uji jarak Duncan

Berdasarkan hasil pengamatan selama 6 MST menunjukkan bahwa pemberian media tumbuh memberikan pengaruh yang tidak nyata pada diameter batang anggrek. Hal ini menunjukkan bahwa pemberian Vitamin B1 dan Atonik menunjukkan pengaruh yang tidak berbeda pada semua konsentrasi yang diberikan pada diameter batang anggrek. Menurut Widiastoety (2009) pemberian vitamin berperan dalam proses pertumbuhan sebagai katalisator dalam metabolisme (Widiastoety 2009).

Pada tahap aklimatisasi planlet membutuhkan vitamin B1 karena dapat mengurangi shock pada tanaman setelah pemindahan media dan memacu pertumbuhan akar tanaman anggrek yang baru dikeluarkan dari botol kultur jaringan (Purnami, 2014). Sedangkan menurut Zulkarnain (2009) atonik merupakan zat pengatur tumbuh termasuk ke dalam golongan auksin yang berbentuk cair yang dapat mempercepat proses perkecambahan, merangsang pertumbuhan akar tanaman, pengaktifan penyerapan unsur hara, mendorong pertumbuhan vegetatif serta meningkatkan keluarnya kuncup.

\section{Jumlah Daun (Helai}

Hasil penelitian pada jumlah daun (helai) anggrek menunjukkan pengaruh yanh nyata pada umur 6 MST dapat dilihat pada tabel di bawah ini.

Tabel 4. Rangkuman Analisis Sidik Ragam Jumlah Daun Anggrek setelah Pemberian Vitamin B1 dan Atonik $(\mathrm{cm})$

\begin{tabular}{lccccccc}
\hline \multirow{2}{*}{ SK } & \multicolumn{3}{c}{ F. Hitung } & \multicolumn{3}{c}{ F. Tabel } \\
\cline { 2 - 8 } & $2 \mathrm{mst}$ & $3 \mathrm{mst}$ & $4 \mathrm{mst}$ & $5 \mathrm{mst}$ & $6 \mathrm{mst}$ & $\mathrm{F}_{0,05}$ & $\mathrm{~F}_{0,01}$ \\
\hline A & $0,89 \mathrm{tn}$ & $1,14 \mathrm{tn}$ & $1,17 \mathrm{tn}$ & $1,01 \mathrm{tn}$ & $0,25 \mathrm{tn}$ & 3,29 & 5,42 \\
B & $2,48 \mathrm{tn}$ & $0,14 \mathrm{tn}$ & $0,11 \mathrm{tn}$ & $0,12 \mathrm{tn}$ & $3,43 *$ & 3,29 & 5,42 \\
AXB & $0,71 \mathrm{tn}$ & $0,18 \mathrm{tn}$ & $0,13 \mathrm{tn}$ & $0,07 \mathrm{tn}$ & $0,51 \mathrm{tn}$ & 2,59 & 3,89 \\
\hline KK & $19,58 \%$ & $23,15 \%$ & $22,54 \%$ & $20,02 \%$ & $10,20 \%$ & & \\
\hline
\end{tabular}

Keterangan: Angka yang diikuti oleh huruf yang sama pada kolom yang sama berbeda nyata pada taraf $\alpha$ $=0.05$ (huruf kecil) berdasarkan uji jarak Duncan

Hasil penelitian menunjukkan pemberian atonik berpengaruh nyata pada jumlah daun pada anggrek pada umur 6 MST. Terlihat bahwa B3 dan B2 menunjukkan perlakuan terbaik pada jumlah daun dengan rata-rata daun yang terbentuk yaitu 15,63 helai dan 
15,13 helai (Lampiran 4). Hal ini menunjukkan pemberian atonik berpengaruh positif pada pembentukan daun anggrek.

Menurut Hartati (2010) pemberian atonik $1 \mathrm{ml} / \mathrm{l}$ mampu merangsang pembentukan daun pada anggrek dendrobium sp pada saat aklimatisai. Atonik merupakan zat pengatur tumbuh golongan auksin. Menurut Zulkarnain (2009) respon tanaman terhadap auksin berhubungan dengan konsentrasi auksin yang diberikan dan tergantung dari kepekaan organ tanaman terhadap auksin.

Respon batang terhadap auksin terbilang cukup besar sehingga pengaruh auksin dalam meningkatkan pertumbuhan vegetatif tanaman lebih terlihat nyata. Jika pemberian konsentrasi lebih tinggi dari konsentrasi optimum maka akan mendorong pertumbuhan atau dapat mengganggu metabolisme dan perkembangan tumbuhan. Hal ini disebabkan karena pada konsentrasi auksin yang tinggi, proses perbesaran sel dapat berlangsung cepat dan sel akan menjadi besar. Keadaan seperti ini akan menyebabkan reaksi turgol sel dalam sehingga permeabilitas terganggu dan sel akan mengalami kekeringan (Riyadi, 2014).

\section{Panjang Akar primer (cm)}

Hasil penelitian pada Panjang akar primer (cm) anggrek menunjukkan pengaruh yang nyata pada umur 6 MST dapat dilihat pada tabel di bawah ini.

Tabel 5. Rangkuman Analisis Sidik Ragam Panjang Akar Primer Akibat Pemberian Vitamin Bı dan Atonik $(\mathrm{cm})$

\begin{tabular}{lccc}
\hline \multirow{2}{*}{ SK } & F. Hitung & \multicolumn{2}{c}{ F. Tabel } \\
\cline { 2 - 4 } & $6 \mathrm{mst}$ & F0,05 & F0,01 \\
\hline A & $1,99 \mathrm{tn}$ & 3,29 & 5,42 \\
B & $3,34 *$ & 3,29 & 5,42 \\
AXB & $2,06 \mathrm{tn}$ & 2,59 & 3,89 \\
\hline KK & $12,68 \%$ & & \\
\hline
\end{tabular}

Keterangan: Angka yang diikuti oleh huruf yang sama pada kolom yang sama berbeda nyata pada taraf $\alpha$ $=0.05$ (huruf kecil) berdasarkan uji jarak Duncan

Hasil penelitian menunjukkan pemberian atonik berpengaruh nyata pada Panjang akar primer anggrek pada umur 6 MST. Terlihat bahwa pemberian pada B3 menunjukkan perlakuan terbaik pada Panjang akar primer dengan rata-rata Panjang akar primer yang terbentuk yaitu $26,63 \mathrm{~cm}$. Hal ini menunjukkan pemberian atonik berpengaruh positif pada penjang akar anggrek. Menurut Zulkarnain (2009) atonik merupakan zat pengatur tumbuh golongan auksin yang berperan dalam merangsang pembentukan akar dan pemanjangan akar. Hasil penelitian Nasution (2016) auksin mampu merangsang pemanjangan akar kentang. Respon tanaman terhadap auksin terbilang cukup besar sehingga pengaruh auksin dalam meningkatkan pertumbuhan vegetatif tanaman lebih terlihat nyata. 


\section{Jumlah Akar}

Hasil penelitian pada jumlah akar anggrek menunjukkan pengaruh yang nyata pada umur 6 MST dapat dilihat pada tabel di bawah ini.

Tabel 6. Rangkuman Analisis Sidik Ragam Jumlah Akar Tanaman Akibat Pemberian Vitamin B1 dan Atonik

\begin{tabular}{lccc}
\multicolumn{2}{c}{$(\mathrm{cm})$} & & \multicolumn{2}{c}{ F. Tabel } \\
\cline { 2 - 4 } SK & F. Hitung & F0,05 & F0,01 \\
\hline A & 6 mst & 3,29 & 5,42 \\
B & 1,56 th & 3,29 & 5,42 \\
AXB & $3,33 *$ & 2,59 & 3,89 \\
\hline KK & $0,43 \mathrm{tn}$ & & \\
\hline
\end{tabular}

Keterangan: Angka yang diikuti oleh huruf yang sama pada kolom yang sama berbeda nyata pada taraf $\alpha$ $=0.05$ (huruf kecil) berdasarkan uji jarak Duncan

Hasil penelitian menunjukkan pemberian atonik berpengaruh nyata pada pembentukan akar anggrek pada umur 6 MST. Terlihat bahwa pemberian pada B3 menunjukkan perlakuan terbaik pada pembentukan akar dengan rata-rata akar yang terbentuk yaitu 6,26. Hal ini menunjukkan pemberian atonik berpengaruh positif pada pembentukan akar anggrek. Hasil penelitian Hartati (2010) pemberian atonik $1 \mathrm{ml} / \mathrm{l}$ merupakan perlakuan terbaik dalam merangsang pembentukan akar anggrek.

Menurut Zulkarnain (2009) atonik merupakan zat pengatur tumbuh golongan auksin yang berperan dalam merangsang pembentukan akar dan pemanjangan akar. Menurut Marlin (2008) bahwa kinetin pada tanaman akan memunculkan efek-efek sekunder yang menjadi penyebab langsung dari pembentukan akar. Auksin endogen punya peran dalam pembentukan dan pemanjangan akar dan juga media aklimatisasi mendukung pertumbuhan dan perkembangan akar.

\section{SIMPULAN}

Pemberian vitamin B1 dan Atonik menunjukkan persentase hidup anggrek yaitu nyata $100 \%$ hidup. Pemberian Vitamin B1 berpengaruh nyata terhadap tinggi tanaman anggrek tetapi berpengaruh tidak nyata terhadap diameter batang, jumlah daun, panjang akar primer dan jumlah akar anggrek. Pemberian Atonik berpengaruh nyata terhadap jumlah daun, panjang akar primer dan jumlah akar anggrek tetapi berpengaruh tidak nyata pada tinggi tanaman, dan diameter batang anggrek. Kombinasi antara kedua faktor perlakuan berpengaruh tidak nyata terhadap tinggi tanaman, diameter batang, jumlah daun, panjang akar primer dan jumlah akar.

\section{DAFTAR PUSTAKA}

Direktorat Jenderal Hortikultura. (2008). Statistik Produksi Tanaman Hias di Indonesia.200,32007.Dalamhttp://www.hortikultura.deptan.go.id/index..php?=comcontent\&task View\&id=124\&itemed=160. Diakses tanggal 22 April 2009

Hartati, S. (2010). Pengaruh macam ekstrak bahan organic dan zpt terhadap pertumbuhan planlet anggrek hasil persilangan pada media kultur. Caraka Tani, 25(1)1: 101-105

Limarni, L . (2008). Pertumbuhan Anggrek (Dendrobium sp) Dalam Kompot Pada Beberapa Jenis Media Tanam dan Konsentrasi Vitamin B1.Tangerang. Jerami Volume 1.No 1 ISSN 1979-0228

Marlin. (2008). Upaya Penyediaan Bibit Pisang Ambon Unggulan Provinsi Bengkulu dengan Pembentukan Planlet Secara In Vitro. Bengkulu. Laporan hasil penelitian tahun II hibah bersaing. (Online), tersedia: https://www.google.com/url? Sa $=\mathrm{t} \& \mathrm{rct}=\mathrm{j} \& \mathrm{q}=\& \mathrm{esrc}=\mathrm{s} \&$ source $=$ web \& $\mathrm{cd}=\mathrm{czd}=\mathrm{rja} \& \mathrm{uact}=8$ 
Riski Abdul Latif, syahbudin Hasibuan dan Siti Mardiana, Stimulasi pertumbuhan dan Perkembangan

\& ved $=0$ ah UKE wj E76 jit 6b VAhUBa FAKHURD4YQ Fggo MAA \& ur = http \% 3 A \% 2 F \% 2Frepository. unib.ac.id \% 2F8004 \% 2F1 \% 2FHB \% 2520

Munir. (2016). Pengaruh Kadar Thiamine (Vitamin B1) Terhadap Pertumbuhan Jamur Tiram Putih (Pleurotus ostreatus). Palembang. Jurnal Biota, 2(2)

Purnami, N. (2014). Pengaruh Jenis dan Frekuensi Penyemprotan Leri Terhadap Pertumbuhan Bibit Anggrek Phalaeonopsis sp. Pasca Aklimatisasi. Bali. EJurnal Agroteknologi Tropika ISSN: 2301-6515

Riyadi. (2002). "Pelatihan Kultur Jaringan Tanaman Angkatan ke-enam”. Aklimatisasi Bibit Tanaman Hasil Perbanyakan dengan Teknik Kultur Jaringan. Serpong

Riyadi, I. (2014). Media Tumbuh: Penggunaan Zat Pengatur Tumbuh dan Bahan-bahan Lain. Materi disampaikan pada Pelatihan Kultur Jaringan Tanaman Perkebunan. BPBPI Bogor pada tanggal, 19-23 Mei 2014.

Widiastoety, D. (2009). Pengaruh Thiamin terhadap Pertumbuhan Planlet Anggrek Oncidium Secara In Vitro. Cianjur. J. Hort. 19(1): 35-39.

Widiastoety, D., N. Solvia, M. Soedarjo. (2010). Potensi Anggrek Dendrobium Dalam Meningkatkan Variasi Dan Kualitas Anggrek Bunga Potong. Balai Penelitian Tanaman Hias. Jurnal Litbang Pertanian, 29(3), 2010.

Yusnita. (2004). Kultur Jaringan Cara memperbanyak Tanaman Secara Efisien. AgroMedia Pustaka. Jakarta. $103 \mathrm{hlm}$.

Zulkarnain, H. (2009). Kultur Jaringan Tanaman. Jakarta: Bumi Aksara 